\title{
2007 GSA Annual Meeting Presidential Address: There's Adventure in Geology
}

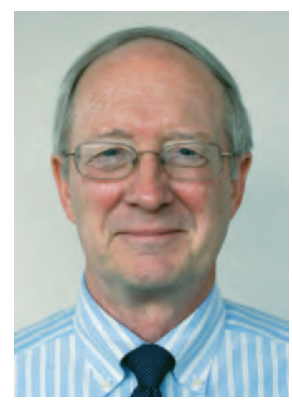

John M. Sharp, Jr., Department of Geological Sciences, The University of Texas at Austin, 1 University StationC1100, Austin, Texas 78712, USA, jmsharp@mail.utexas.edu

There's Adventure in Geology (May, 1959) is a book that was written for young people in the late 1950s. It was given to my wife by one of her best friends before we were married with the admonition, "If you are going to marry a geologist, you have to read this." In my opinion, it wasn't really a great book, but I can certainly attest that the title is true! As president of the Geological Society of America, it is my privilege to write this 2007 address, in which I wish to stress several points: the uniqueness and the adventure of our science, its importance to society, and some of the key issues that confront us as both scientists and citizens. I illustrate some of these points with some snippets of my own research-my scientific odyssey. This address could also have been called "The Privilege of Being a Geologist," paraphrasing Victor Weisskopf's (1989) The Privilege of Being a Physicist, for we are a privileged group.

My scientific odyssey has taken me to places that I never would have imagined in my youth and early career. I suspect that many of you who read this will have similar feelings. Who would have thought - I certainly didn't — that I would conduct field studies and present papers in Egypt (e.g., Bennett et al., 2002), Australia (Robinson et al., 1998), the UK (e.g., Sharp, 1997), México (e.g., Gary et al., 2003; Andring et al., 2006), and Italy (e.g., Sharp et al., 1982), as well as many U.S. states, most notably Missouri (e.g., Grannemann and Sharp, 1979) and Texas (e.g., Sharp and Banner, 1997, 2000; Uliana and Sharp, 2001)? Fascinating geoscientific problems are everywhere. There is much we don't know and new problems still unimagined. Science, especially geology, is not dead!

International scientific meetings give us an opportunity to meet fascinating scientists from the entire globe. The Geological Society of America provides us a superb platform from which to present our research findings and ideas (as the references prove). GSA and our Allied and Associated Societies provide scientific stimulation, exposure to new ideas, and a great opportunity for camaraderie with fellow scientists. I could not have imagined 35-40 years ago that my research path would have looked at processes in great sedimentary basins (e.g., Sharp and Domenico, 1976; McKenna and Sharp, 1998), surface water-groundwater interactions in major alluvial systems (e.g., Sharp, 1988; Larkin and Sharp, 1992), analysis of free convection (e.g., Simmons et al., 2001), interbasinal and regional flow studies in semi-arid regions of North America (e.g., Sharp, 1989; Mayer and Sharp, 1998), the dominating role of fractures in hydrogeologic systems (e.g., Krasny and Sharp, 2007), the effects of urbanization on groundwater systems (e.g., Garcia-Fresca and Sharp, 2005; Wiles and Sharp, 2007), and karst hydrology (e.g., Halihan et al., 2000; Wolaver et al., 2006, 2007). I never conceived that I would have been even remotely associated with exploring Earth's deepest water-filled sinkholes as a prelude to eventual exploration of the solar system (Gary and Sharp, 2006). Scientific opportunities are constantly offering themselves to us for study. To the geologists of the future: you are lucky; who knows what scientific adventures await you and where they will take you. Have fun! Truly, there is adventure in geology.

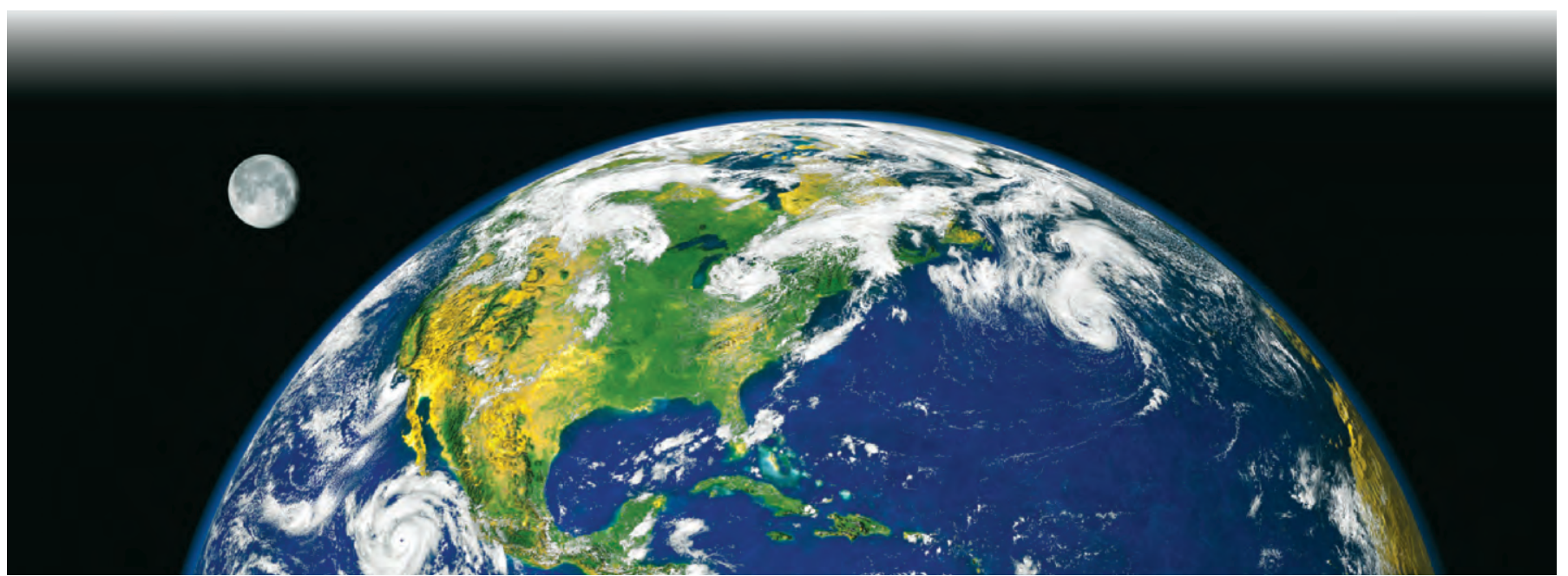

Image by Stöckli, Nelson, Hasler Laboratory for Atmospheres Goddard Space Flight Center, http://rsd.gsfc.nasa.gov/rsd.

GSA Today: v. 18, no. 1, doi: 10.1130/GSAT01801A.1 
We geologists are a fortunate group of scientists. We work over a range of spatial and temporal scales that is rivaled only by the cosmologists. We look for minute chemical traces of life in ancient rocks and examine isotopic ratios, but we are also looking at deep earth structures and the evolution of the solar system where geology provides the ground-truth data. Unique to our science is the fact that we are concerned with both prediction and retrodiction of the processes that shape the world upon which we live. We are trying to decipher 4.5 billion years of Earth's history. The idea of geologic time (deep time), the evolution of life, and the concept of uniformitarianism are a few of our science's many gifts to mankind. It might, however, be geology's projections of earth processes into the future that are the most important. Much of the early growth of geology was driven by the prediction aspect. Where to find key mineral resources and how much of them exist were questions that led to support for geological mapping and the formation of our geological surveys. These remain critical projectionswhat are our petroleum, mineral, and water resources? These issues are important politically and economically. One of my first professional slides (Sharp and Domenico, 1976, Figure 2 therein) depicted sedimentary basins in the eastern hemisphere that are receiving such high rates of sediment deposition that they are predicted to contain excess pore-fluid pressures. For many of them, excess pore-fluid pressures had been reported in the literature before 1973, and most have since had such pressures documented. It is an interesting coincidence that these basins seem to correspond with zones of recent political turmoil. Of course, we either have found or expect to find petroleum in these basins. This may not be a coincidence, because wars have commonly commenced over possession of mineral, water, land, and now energy resources. Geology is important politically.

Perhaps the great question of today is-how large a population can a state or region or the world sustain given predicted climate, geologic, hydrologic, technical, and socioeconomic changes? The failure to project these changes and their probable effects continues to be a major source of political and economic conflict.

Prediction of geologic hazards is also critical. In some cases, we do this relatively well-flood stages and major volcanic eruptions are examples-in other cases, we are less precise, such as in predicting major earthquakes, catastrophic subsidence, or the effects of mankind as a primary geologic agent of change. On much of the world's land surface, it is difficult to find a square kilometer that hasn't been profoundly affected by mankind. We are, perhaps, the major geologic agent affecting Earth's surface. Finally, our field of research has expanded beyond planetary confines.

The adventure is there; our predictions involve the real world; even children are excited about geology-they can sense that adventure!

Our challenges are exciting, and daunting. They include

- Appreciation of deep time and Earth's evolution. Clearly, any society that denies either fundamental scientific facts or scientific uncertainty is in big trouble. We as scientists have to bring our knowledge to the public and do it repeatedly.

- Integrating science, especially geology, into public policy decision making. For instance, we can predict sea level rise and floods, but we continue to build within one meter of mean sea level and on flood plains, areas that we are sure will be inundated eventually. We just cannot predict the timing. Are we rebuilding New Orleans in a rational manner? How do we communicate science to politicians, the business community, and the public?

- Population growth and urbanization. What is the maximum population Earth can sustain and which geographic locations are better than others? How do we best, if we can, find the energy, water, and agricultural productivity to meet the demands? Have we already passed sustainable levels?

- Environmental and climatic change. Geologists are in a unique position-we have documented significant changes over Earth's history. How do we predict the effects more precisely and how do we deal with the predicted change?

- Science and learning for its own sake. A line of research may not have an immediate practical value, but learning for its own sake must be fostered. We don't have to look far to find examples of "dreamer" science later turning out to be of immense practical value. Just because research doesn't have an immediate expected payback doesn't mean it should not be pursued. Follow your scientific insights!

We need to support science and push for financial support of science at all levels whether or not it is basic or applied and whether or not it is immediately practical or "blue sky." The rewards will be great, and the failure to do so will have very negative ramifications.

If addressing these challenges isn't an adventure, what is? We are indeed lucky to be geologists. Rock on! The adventure continues!

\section{REFERENCES CITED}

Andring, M.J., Wolaver, B.D., Sharp, J.M., Jr., and Banner, J.L., 2006, Analyzing groundwater flowpaths in a karstic basin using cross-plots of major ions: Cuatro Cienegas Basin, Coahuila, Mexico: Geological Society of America Abstracts with Programs, v. 38, no. 7, p. 288.

Bennett, P.C., Sharp, J.M., Jr., El-Shishtawy, A., Atwia, M.G., Bakrah, A., and Noweir, A.-H., 2002, Hydrogeology and trace metal geochemistry in the Central Nile Delta, Egypt: Geological Society of America Abstracts with Programs, v. 34, no. 6, p. A-85.

Garcia-Fresca, B., and Sharp, J.M., Jr., 2005, Hydrogeologic considerations of urban development-Urban-induced recharge, in Ehlen, J., Haneberg, W.C., and Larson, R.A., eds., Humans as Geologic Agents: Geological Society of America Reviews in Engineering Geology, v. XVI, p. 123-136.

Gary, M.O., and Sharp, J.M., Jr., 2006, Volcanogenic karstification of Sistema Zacatón, in Harmon, R.S., and Wicks, C.M., eds., Perspectives on Karst Geomorphology, Hydrology, and Geochemistry-A Tribute Volume to Derek C. Ford and William B. White: Geological Society of America Special Paper 404, p. 79-89.

Gary, M.O., Sharp, J.M., Jr., Caramana, G., and Havens, R.S., 2003, Volcanically influenced speleogenesis forming El Sistema Zacatón, México, and Pozzo Merro, Italy, the deepest phreatic sinkholes in the world: Geological Society of America Abstracts with Programs, v. 35, no. 6, p. 52.

Grannemann, N.G, and Sharp, J.M. Jr. 1979, Alluvial hydrogeology of the lower Missouri River Valley: Journal of Hydrology, v. 40, no. 1-2, p. 85-99, doi: 10.1016/0022-1694(79)90089-1. 
Halihan, T., Mace, R.E., and Sharp, J.M., Jr., 2000, Flow in the San Antonio segment of the Edwards aquifer: matrix, fractures, or conduits?, in Sasowsky, I.D., and Wicks, C.M., eds., Groundwater Flow and Contaminant Transport in Carbonate Aquifers: Rotterdam, A.A. Balkema, p. 129-146.

Krasny, J., and Sharp, J.M., Jr., eds., 2007, Groundwater in Fractured Rocks: Selected Papers 9, International Association of Hydrogeologists: London, Taylor \& Francis, $646 \mathrm{p}$

Larkin, R.G., and Sharp, J.M., Jr., 1992, On the relationship between river basin geomorphology, aquifer hydraulics, and ground-water flow direction in alluvia aquifers: Geological Society of America Bulletin, v. 104, p. 1608-1620, doi: 10.1130/0016-7606(1992)104<1608:OTRBRB>2.3.CO;2.

May, J., 1959, There's Adventure in Geology: Chicago, Popular Mechanics Press, $160 \mathrm{p}$.

Mayer, J.R., and Sharp, J.M., Jr., 1998, Fracture control of regional ground-water flow in a carbonate aquifer in a semi-arid region: Geological Society of America Bulletin, v. 110, p. 269-283, doi: 10.1130/0016-7606(1998)110<0269:FCO $\mathrm{RGW}>2.3 . \mathrm{CO} ; 2$

McKenna, T.E., and Sharp, J.M., Jr., 1998, Radiogenic heat production in sedimentary rocks of the Gulf of Mexico Basin: AAPG Bulletin, v. 82, p. 484-496.

Robinson, N.I., Sharp, J.M., Jr., and Kreisel, I., 1998, Contaminant transport in sets of parallel finite fractures with fracture skins: Journal of Contaminant Hydrology, v. 31, p. 83-109, doi: 10.1016/S0169-7722(97)00055-7.

Sharp, J.M., Jr., 1988, Alluvial aquifers along major rivers, in Back, W., Rosenshein, J.S., and Seaber, P.R., eds., Hydrogeology: Geological Society of America, The Geology of North America, v. O-2, p. 273-282.

Sharp, J.M., Jr., 1989, Regional ground-water systems in northern Trans-Pecos Texas, in Muehlberger, W.R., and Dickerson, P.W., eds., Structure and Stratigraphy of Trans-Pecos Texas: 28th International Geological Congress Field Trip Guidebook T317, p. 123-130.

Sharp, J.M., Jr., 1997, Ground-water supply issues in urban and urbanizing areas, in Chilton, J., ed., Groundwater in the Urban Environment: Problems, Processes and Management: Proceedings of the 27th Congress, International Association of Hydrogeologists, Nottingham, Rotterdam, A.A. Balkema, v. 1, p. 67-74.
Sharp, J.M., Jr., and Banner, J.L., 1997, The Edwards aquifer-a resource in conflict: GSA Today, v. 7, no. 8, p. 1-9.

Sharp, J.M., Jr., and Banner, J.L., 2000, The Edwards Aquifer: Water for thirsty Texans, in Schneiderman, J.S., ed., The Earth Around Us: Maintaining a Livable Planet New York, W.H. Freeman, p. 154-165.

Sharp, J.M., Jr., and Domenico, P.A., 1976, Energy transport in thick sequences of compacting sediments: Geological Society of America Bulletin, v. 87, p. 390400, doi: 10.1130/0016-7606(1976)87<390:ETITSO>2.0.CO;2.

Sharp, J.M., Jr. Klemm, D.D., and Wagner, J., 1982, Hydrogeologic controls on the hydrothermal systems and on the occurrences of antimony and mercury deposits in Tuscany, Italy: Geological Society of America Abstracts with Programs, v. 15, no. 7, p. 614 .

Simmons, C.T, Fenstemaker, T.R, and Sharp, J.M.,Jr, 2001, Variable-density groundwater flow and solute transport in heterogeneous porous media: Approaches, resolutions and future challenges: Journal of Contaminant Hydrology, v. 52 , p. 245-275, doi: 10.1016/S0169-7722(01)00160-7.

Uliana, M.M and Sharp, JM Ir, 2001, Tracing regional flow paths to major springs in Trans-Pecos Texas using historical geochemical data: Chemical Geology, v. 179, p. 53-72, doi: 10.1016/S0009-2541(01)00315-1.

Weisskopf, V.F., 1989, The Privilege of Being a Physicist: New York, W.H. Freeman and Company, 235 p.

Wiles, T.J., and Sharp, J.M., Jr., 2007, The secondary permeability of "impervious" cover: Geological Society of America Abstracts with Programs, v. 38, no. 6, p. 473.

Wolaver, B.D., Sharp, J.M., Jr., and Rodriguez, J.M., 2006, Gravity geophysical analysis of spring locations in a karstic desert basin, Cuatro Cienegas Basin, Coahuila, Mexico: Transactions of the Gulf Coast Association of Geological Societies, v. 56, p. 885-897.

Wolaver, B.D., Sharp, J.M., Jr., and Ibarra, J.C., 2007, Aquifer delineation for groundwater management in a developing karstic basin: Cuatrociénegas, Coahuila, Mexico: Geological Society of America Abstracts with Programs, v. 38, no. 6, p. 37.

\section{GeoCorps Positions Open for Application}

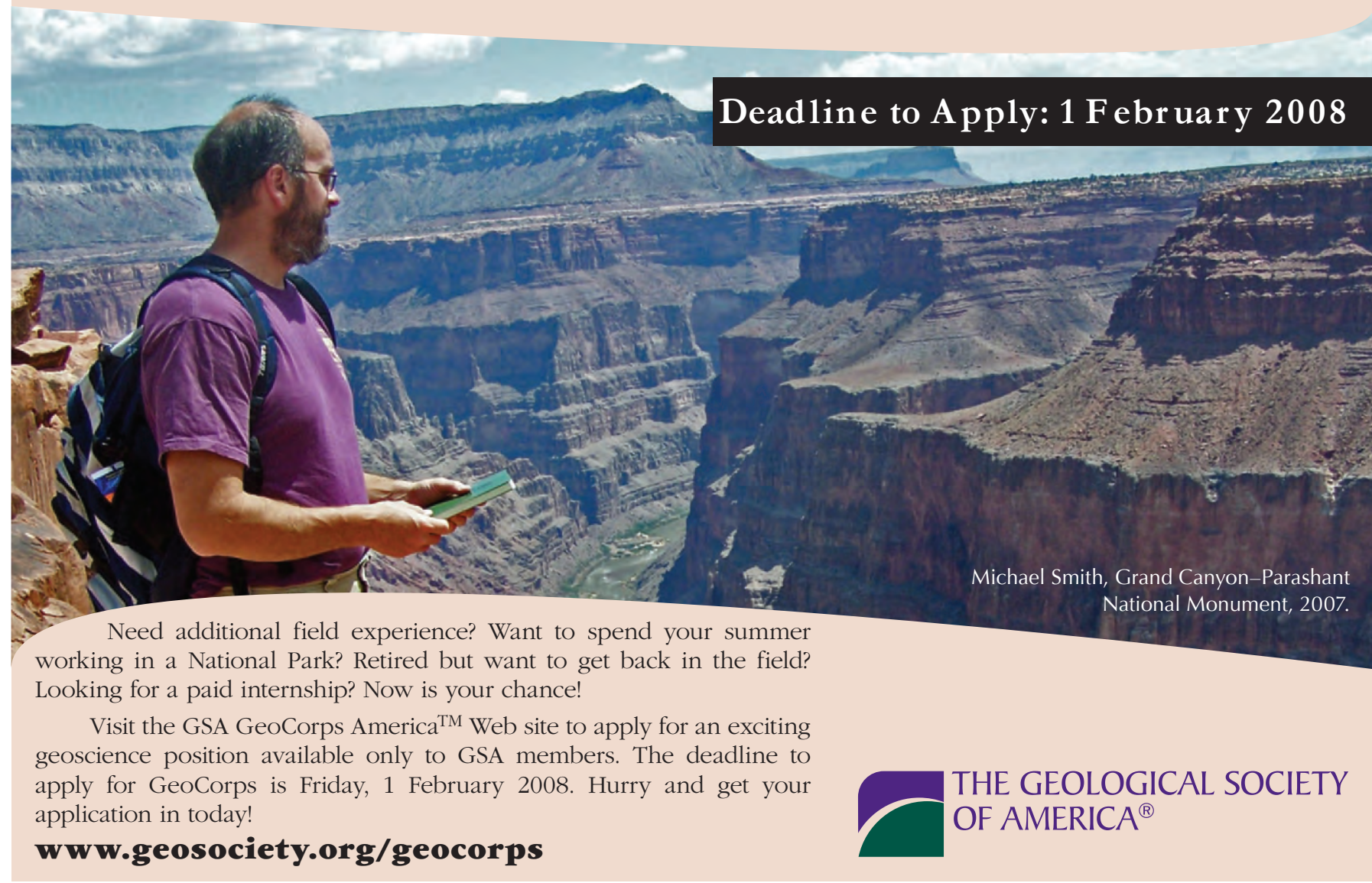

